\title{
Margaret McCartney: Does the GMC deserve its current powers?
}

\author{
Margaret McCartney general practitioner, Glasgow
}

The General Medical Council recently published its consultation on "how we deal with concerns about doctors." It wants "serious" sanctions on doctors who have "failed to raise concerns where there is a reason to believe a colleague's fitness to practise is impaired" or "where a patient is not receiving basic care."

It wants to force doctors to apologise for mistakes and aims to apply sanctions for previous, rectified errors, to "maintain public confidence" in the profession. But it sounds more like a plea for confidence from the public, or from politicians.

Any doctor can be clever, kind, dedicated-and still screw up, the GMC admits. ${ }^{2}$ What should matter is how we react.

Humiliation and punishment do not encourage the open discussion of individual failures that is necessary for systematic safety improvements.

The GMC also wants more control of doctors' personal lives: it already said that they should not be anonymous on social media. ${ }^{2}$ This recommendation is absurd (do we really want to disallow pseudonyms and give the GMC the right to the registration number of every doctor who wants to make any comment on health?), as is its wish for more power to sanction "any other behaviour that may undermine public confidence in doctors." But who decides what "public confidence" is? Why shouldn't we be allowed to spend our off-duty weekends drinking, swearing, and dancing on tables?

Is the GMC worthy of its current powers? It has instigated a non-evidence based screening test for doctors (revalidation), while acting too slowly on symptomatic concerns. One whistleblower, Peter Wilmshurst, reported several cases of medical misconduct but has alleged repeated delays in investigations. Is it acceptable that investigations have taken years rather than weeks? Shouldn't we expect that any concerns raised are dealt with rapidly?

A quick Google search confirms dozens of GMC registered doctors claiming non-evidenced and expensive interventions, such as vitamin infusions for hangovers, milk thistle for cancer, and tests for "adrenal stress." Sick doctors have reported being traumatised by GMC investigations, ${ }^{4}$ and we await its report into suggestions that this has led to suicide.
A few doctors truly are bad; but, if you listen, people will tell you who they are. Of similar concern is where good doctors are put under bad pressure. Where are the "serious" sanctions for managers who don't hire enough staff, or for politicians who create a constantly distracting sea of boxes to tick when we should be listening to patients, or for referral management schemes that spoil interprofessional communication?

Underfunding of mental health and cuts to social care have directly increased the primary care workload. GPs cannot safely see 40 or 50 patients a day, with two or three problems each, and not slip up. If the GMC can't recognise this, we need a regulator that can.

Competing interests: I have read and understood the BMJ policy on declaration of interests and declare the following interests: I'm an NHS GP partner, with income partly dependent on Quality and Outcomes Framework points. I'm a part time undergraduate tutor at the University of Glasgow. I've written a book and earned from broadcast and written freelance journalism. I'm an unpaid patron of Healthwatch. I make a monthly donation to Keep Our NHS Public. I'm a member of Medact. I'm occasionally paid for time, travel, and accommodation to give talks or have locum fees paid to allow me to give talks but never for any drug or public relations company. I was elected to the national council of the Royal College of General Practitioners in 2013.

Provenance and peer review: Commissioned; not externally peer reviewed.

Follow Margaret McCartney on Twitter, @mgtmccartney

1 General Medical Council. Reviewing how we deal with concerns about doctors: a public consultation on changes to our sanction guidance and on the role of apologies and warnings. 22 August 2014. www.gmc-uk.org/concerns/25346.asp.

2 General Medical Council. Good medical practice: explanatory guidance. Doctors' use of social media. 25 March 2013. www.gmc-uk.org/Doctors use of social_media.pdf 56006300.pdf.

3 Hammond P. Private Eye, issue 1369: inquiring into the GMC. 3 July 2014. http:// drphilhammond.com/blog/2014/07/03/private-eye/private-eye-issue-1369/.

4 Moberly T. GMC is traumatising unwell doctors and may be undermining patient safety, Gerada says. BMJ Careers 20 May 2014. http://careers.bmj.com/careers/advice/viewarticle.html?id=20017662.

Cite this as: BMJ 2014;349:95959

(๑) BMJ Publishing Group Ltd 2014 
